\title{
Teaching somatic idioms during the corona crisis (based on historical and literary texts)
}

\author{
Botagoz Suiyerkul - Altynshash Kurmanali - Bakhytgul Smanova - Kuralay \\ Aitmukhambetova - Gulmira Bayalieva
}

DOI: 10.18355/XL.2021.14.01.07

\begin{abstract}
By the last millennium of the twentieth century, phraseology was established as an independent branch of linguistics, and now it is being developed in several directions. One of them is the theory of idioethnic phraseology. This doctrine considers the asymmetry in phraseology and the semantic description of the resulting phraseological units $(\mathrm{PhU})$, the concept of phraseological paradigm $(\mathrm{PhP})$, the "cap" as a phraseological category, and its relationship to phraseological derivation. This paper focuses on phraseological units and the difficulties in teaching students during the corona crisis. We use the World Bank's data on Kazakhstan (summer 2020), building on the narrative that "the COVID-19 pandemic has a negative impact on the development of human capital not only in Kazakhstan, but all over the world. Uneven access to quality education, especially during the quarantine period, can negatively affect the development of human beings." Because of said challenges, many educational establishments transferred the education system to distance learning. Teaching languages, especially when teaching phraseology, requires a lot of strength, a good grasp of modern technology, and innovative approaches. The aim of our research is to identify (1) the semantic field of the somatic idioms based on relevant historical and literary texts and (2) viable ways of teaching students during the corona crisis.
\end{abstract}

Key words: somatic idioms, phraseological phrases, semantics, semantic field, historical text, literary text, corona crisis, teaching

\section{Introduction}

The COVID-19 pandemic brought extreme challenges to the functionality of education systems globally. It has affected almost 1.6 billion students in more than 190 countries and on all continents. The closing of schools and other educational institutions resulted in a 94 percent decline in global school attendance. In lowincome countries, the indicator was down by 99 percent. The pandemic crisis has exacerbated the existing problem of inequality in the sphere of education.

Some argue that the crisis has served as an incentive for innovations in the field of education. Though this may have been the case in some contexts, we should not consider the pandemic a virtue conducive to educational development. Nevertheless, in an attempt to ensure the continuity of professional training, innovative approaches had to be implemented in all school environments: from radio and television broadcasts to on-line teaching platforms, students were exposed to relevant ideas and study materials, which then enabled them to study at home. Thanks to the adoption of prompt operative measures by state and local governments and partner institutions, the uninterrupted educational process could continue. The group of active agents in this process included the Global Coalition on Education that dealt with educational issues under the auspices of UNESCO. Adequate solutions for distance learning were thus developed and made available on a global scale. The situation served as a reminder of the importance of teachers and an adequate support structure in education facilitated by governments and other stakeholders on all levels.

XLinguae, Volume 14 Issue 1, January 2021, ISSN 1337-8384, eISSN 2453-711X 
In order to solve said problems, it was necessary to prepare new materials, innovative programs, shoot video lessons, develop new rules for teaching, establish new procedures of assessment and instructions, identify new ways of conducting training courses for teachers, deploy specialized Internet platforms for distance learning and explain these new measures and tools to the parents and the public. (Zahorec, Haskova, Munk, 2019). Considering the existing problems and opportunities, after studying international experience, recommendations of UNESCO and the World Bank, we decided to use several distance learning technologies at once: training via the Internet; training through television and radio; and regular training in remote villages.

In this research paper, we will discuss the phraseology problem and specifics in teaching. Firstly we will clarify what phraseology is and how we apply it in teaching students. Given the fact that phraseology is one of the essential aspects of teaching/learning languages, it requires a lot of focused attention.

Language phraseology has been the subject of special attention among linguists from different countries throughout the past century. The need for language teaching and translation studies' development gave impetus to the comparative study and description of languages. The ongoing comparative study of the lexicology of languages led scientists to significant conclusions and opened up new prospects for studying such colorful and expressive means of creating imagery as idiomatic phraseological units of the language.

Idiomatic phraseological expressions belong among the most specific aspects of language, the comparative study of which is of high scientific interest and requires, accordingly, a specific research approach. Idioethnic phraseology is both a theory (idioethnic theory of phraseology) and a branch of phraseology that studies idioethnic marker phraseologies in two or more languages. Its subject is the national specific features of the phraseological system. These include idioethnic features arising from the properties of phraseology inherent in the system of a particular language, cultural and historical data, which are reflected in the linguistic consciousness of its adherents. Published research on phraseology uses the method of comparing analogues of selected units to identify national characteristics. For example, the concepts of lexeme $\rightarrow$ phraseology, prototype of phraseology $\rightarrow$ atomic (fractional) phrase, phraseological meaning $\rightarrow$ phraseosema, phraseology as a pseudonym $\rightarrow$ phraseosymbol, and their content are compared (Akhmanova, 1966). The lexeme used in phraseology is called phraseolex. Phraseolexes in different languages that are in an equivalent, alternative relationship are called isophraseolexes, or they can be abbreviated as isolexes. Isolexes of four, three, and two languages are usually distinguished. Phraseolexes that occur only in one of the considered languages are called idioethnic phraseolexes or idiolexes and are contrasted with isolexes. They consist of two nouns used in the same phraseology. Accordingly, isodiads and idiodiads are distinguished. A set of phraseological units containing a common token forms a phraseological paradigm (Gak, 1975).

Phraseological paradigms, in which words belonging to a common thematic field are the main component, form a phrase-thematic field. For example, in our language, somatic names as individual lexemes "liver" and "heart" belong to the lexicalthematic group, while phraseological lexemes belong to the phraseological field identified as "the inner world of man." In addition, this field includes phraseology, in which the tokens "soul" and "mood" are the main components.

"In the phraseological fragment of the conceptual and linguistic image of the world, the heart is expressed in the form of a material organ that describes the sensory actions associated with the physiological reactions of the human body. The location of the heart is connected with the chest of a person, which is a primitive image of the world, the concentration of quasi-organs and material organs in relation to 
the inner soul of man. In this sense, the heart is used in conjunction

with the quasi-organs 'soul' and 'mood."' (Nurzhanova, 2010: p. 25)

The conceptual and linguistic pictures of the world represent a full base of knowledge about the world, which has been accumulated during the entire history of the nation speaking that language. They represent the phenomenon of mass consciousness of the native speakers of a particular language and are able to convincingly reveal the national and cultural specifics of the images of the consciousness of the different bearers' lingua-cultural communities (Sametova, 2019). The analysis of somatic phraseology, which includes the name "heart," shows that human strength and endurance are also associated with the physiological properties of the heart "in perceiving and resisting the effects of the environment." (Sametova, 2019, p 27). For example, if we take the somatic phraseology of the heart, which means "true hero, brave," which enters the semantic field of "heart-strength," "primitive" linguistic consciousness is a powerful force that can lead to unseen heroism. It also serves as protection from external influences. The authenticity of the primitive "anatomical" information about the "outer hairy membrane of the heart" fixed in the primitive image of the world is reflected in the medical fragment of the scientific image of the world: "The inner surface of the pericardium is called the pericardium. There is serious moisture in the cavity between the pericardium and epicardium. It causes the membranes to become incompatible as the heart contracts. The epicardium and pericardium also belong to the conduction system of the heart." (Potebnya, 1994: p. 86).

In the text of the "Love Letter," the heart is found in the phrase "lion's heart" (lion's heart):

A 107 Zehi lion heart Konrat clan

Hey, lion-hearted, Brown offspring

A 108 Little Yashdin is the eldest of the sons

$\mathrm{K}$. The greatness of the great from an early age

A 109 Happiness is a treasure

$\mathrm{K}$. Happiness is the source, prosperity is the mine

A 110 Muhammad-Khoja-bek Jalam Kuvanji

K. Mohammad Khoja-bek is the joy of the world

A Oza inanimate tan land property without you

Q 111 In your absence, our state was like a soulless body ... (From "Love Letter”) (Sagyndykuly, 2007: p.228).

It is clear that the meaning of this phrase is "a brave, courageous and strong" batyr ruler. This value is especially acute when taken in conjunction with the name "lion." For the lion is the king of the beasts. At the same time, the image of the ruling hero in the medieval linguistic consciousness of Khorezm is fully combined with the image of the Kazakh national linguistic consciousness and cognitive consciousness as a "brave commander and khan." For example, recall what Bukhar Zhyrau said about Abylai Khan. Therefore, it is no exaggeration to say that this is an integral part of the image of the "Ruler," which is accompanied by a number of qualities, such as "foresight, intelligence, cunning ...”. (Sagyndykuly, 2007: p.229)

In this regard, we should pay attention to the last line in the excerpt from the "Love Letter": The author connects the whole state with the human phenomenon: that is, the inaction before the coming to power of Mohammad Khoja-bek, the indifference of the country, its legitimate continuation - the decline and stagnation - always worries the poet. It is known that this is a trend that continued in the later Kazakh society. Even in the 15th-18th centuries after the official recognition of the Kazakh people, this concept, this image became the basis for the formation of a whole literature - Zhyrau

XLinguae, Volume 14 Issue 1, January 2021, ISSN 1337-8384, eISSN 2453-711X 
poetry. Thus, the unity and prosperity of the country is one of the main themes in the works of the Middle Ages, as well as one of the three largest components of the work. These macro-components are listed in the version "Creator - Ruler - Beauty" and form the body of the whole poetic text, that is, it can be recognized as a continuum in the form of "Praise to God" - "Praise to the Ruler" - "Praise to the Beauty of Mankind."

In the linguistic image of the world, liver somatism is used as a direct anatomical name and participates in the formation of the world of words and images related to the kinship of man in the figurative sense. For example, in the phraseology, a child's liver is equated with a child born from the womb, and is used in the sense of a "born child" who breaks his brother. In the primitive cognition of the ethnos, the liver "moves," "hardens," "shrinks," i.e., undergoes physical changes, depending on various typical life situations. For example: the liver is cold, the skin is "broken," the liver is very "cruel," etc. The greatest grief of a person - the loss of a loved one, is associated with the "crushing" of this organ: the crushing of the liver "deeply grieved."

In the Kazakh worldview, the liver is taken as a symbol of the "closest" distance in human relations: the liver "pulled the head," the liver "very close," the liver "held close," the liver is whole, the liver is "children, relatives" - a relative is safe, a brother is unhappy, a "childless woman," a brother "hugs his head, hugs him" or "adopts a child," enters a brother, "has a very close relationship," etc. In the nominative and phraseological fragments of the linguistic image of the world, liver somatism is taken as a symbol of blood kinship (child, brother). (Nurzhanova, 2010).

In the medieval written heritage, these lexemes were used in the versions "liver / liver," "heart," "mind." Among them, there is a wide range of "mood" - the semantic scope and, accordingly, the scope. This is confirmed by the fact that it is used 354 times in the text "Khusrau ua Shyryn" (Ibatov, 1974), and 32 times in "Muhabbatname" (Sagyndykuly, 2007).

As konil (Mood) is coming out from Water, so it should be clean and pure. As dirty water can harm a man's organism: konilge tusken kirbin annoyance/dissatisfaction seized somebody can be harmful to emotional, spiritual world of a man. Similar to what you sow in the ground, then you gather that in the harvest, the same about the Mind, what you learn that will be reasonable and clear and assumed by the spirit (Suiyerkul, 2018). In "Khusrau ua Shyrynda," "liver" is called along with "heart" and forms a diad, and the emotional sphere of a person is characterized by its physiological state: Burning heart is bleeding - burning brother, my heart is bleeding; The burnt liver is full of blood - the burnt liver, the heart is full of blood (Ibatov, 1974).

Thus, it is observed that the variables formed on the basis of the literal meaning of the word vary significantly in the composition of phraseological units. The concentration of several phraseological units (FU) around one phraseology is especially characteristic of a work of art. This is due, on the one hand, to the author's desire to gradually expand the artistic idea, to thicken the color, and on the other hand, to strengthen the influence of the artist on his readers, developing the idea behind the work. Ultimately, this approach, which is in line with the author's pragmatic style, leads to the creation of new phrases, in addition to the existing regular expressions in the language. Thus, variants or equivalents of phraseology arise by replacing individual components of long-known regular expressions with other words. This enriches the phraseological base of the language and expands and transforms the phraseological fields in it.

Now back to the terms in the field of phraseology. The phenomenon of asymmetric dualism in language, discovered by Kartsevsky, was later further developed in the study of language from different angles. The first to pay attention to asymmetry in phraseology was V.G. Gak (Gak, 1975). The scientist revealed the essence of this phenomenon and found that FB combines two types of asymmetry - syntagmatic and paradigmatic (Gak, 1975). From this combined/combined asymmetry emerge the 
three main features of phraseology: polynomial, metaphorical (variability of meaning), and idiomatic. Later V.G. Gak calls these three polylexematic, idiomatic, and elongated, respectively. The first of them distinguishes FB from other units of the whole form, the second - from analytical phrases, and the third - from individualauthorial phrases (Gak, 188, p 78).

Applying the unity of these three signs in relation to the phraseological material, one of the main and controversial issues in the study of phraseology, is the answer to the question of what are the main features of FB. This, in turn, allows you to give a concise and complete definition of phraseology. That is, phraseology is a separately formed unit of language, the components of which have undergone a complete or partial semantic change.

The concept of phraseological paradigm (FP), which begins with the research of V.G. Gak, is the main unit in the comparative analysis of national phraseology in idioethnic phraseology. By comparative analysis of phraseological paradigms, rather than phraseological ones, the substrate material in phraseology can be considered in close connection with vocabulary and the history of ethnic cultures. Studies using this method have shown that two or three languages do not have the same paradigms. This conclusion confirms the idioethnicity of the phraseological system of any language. Diads play a special role in phraseology. It is no coincidence that phraseographers highlight the most commonly used diads in the form of "caps" (Gak, 1998). Because they create a new phraseosema, they participate in phraseological derivation and develop their "own" paradigm. Phraseological units that enter this paradigm as independent units cannot be equal to each other. Because the semantic range of the phraseological lexicons that distinguish them from each other does not completely correspond to each other, the semantic framework of the phraseological units will be somewhat different. This shows that phraseological units that are part of the same phraseological paradigms cannot be considered equal. Although they can be used interchangeably in any context, they differ at the level of phraseology. In this regard, it can be concluded that each phraseology has its own influence on the nature and scope of phraseological paradigms.

\section{Discussion}

In this regard, we would like to focus on the method and techniques of teaching phraseological units and their variants - namely, their explication to students during the corona crisis. As we mentioned before, complete lessons were conducted on-line, which causes problems in understanding the theory and practice of phraseology and phraseological units. The urgent and rather abrupt transfer of in-school training to distance learning during the pandemic required significant changes to facilitate adequate on-line training procedures based on massive, open on-line courses (MOOCs). Educational organizations forced to work with students remotely to reduce the risks of the spread of coronavirus should be aware of this difference when assessing the effectiveness of so-called "on-line learning" using distance learning technologies (DLT). Under the threat of the spread of coronavirus infection, most universities and colleges, on the recommendation of the Ministry of Science and Higher Education, decided to switch to distance learning. In this regard, all face-toface classes, including lectures, practical training, and even laboratory classes with virtual analogues, were transferred to the on-line environment. Teachers are forced to organize the educational process through distance learning technologies based on various methods of delivering electronic content and available communication tools for students and teachers in the electronic information and educational environment (EIE).

Such a sharp transition to "remote learning" is a forced and urgent measure. Not all universities were ready for this radical restructuring of the educational process based

XLinguae, Volume 14 Issue 1, January 2021, ISSN 1337-8384, eISSN 2453-711X 
on objectively different levels of development of their information infrastructure, provision of disciplines with electronic educational resources and readiness of teachers to use digital platforms and services in the educational process. Correctly selected course materials, based on the goals and objectives of learning and the educational process's characteristics in the on-line environment, will provide students with a positive educational result and the teacher with a positive feedback. This approach implies that on-line learning is primarily a cognitive and social process and not just a process of transferring information via the Internet. Just like face-to-face training, on-line learning requires social support for students. In full-time education, this role is played by the material resources of the university and the teachers involved in the educational process. On-line learning is impossible without an IT infrastructure, which requires significant investments, including an on-line learning platform, either owned by the school or leased, as well as high-quality on-line courses that provide effective training and support for learners in an on-line environment. In the current situation, when the transition to on-line learning is carried out as soon as possible, all these conditions must be created in advance, and teachers must have experience in using on-line learning tools and student support services. (Zatkova, Ambrozy, 2019).

Experience shows shows that the development of an on-line course takes on average 6-9 months, and the teacher's skills on the on-line platform are formed during the first two launches of the course.

Taking into consideration all the aspects of distant learning, all the theoretical material of this research was arranged in on-line platforms and presented to students. In the following section below, we present the extracts from the lectures introduced to the students by the IT technology in modules. The problem of explicit transformation of phraseology in modern linguistics arises in connection with the development of the science of phraseology in general, the study of the internal properties of phraseological units, their formation, and use. Despite the fact that there is a lot of work on the phenomenon of the transformation of phraseological units, some issues remain open. One of the issues awaiting further study is the quantitative change in the component composition of phraseological units.

The external form of any language unit is stable and not rigid. This also applies to phraseologies, in the process of which the speaker, especially the author of the literary text, tends to constantly change their meanings and forms in accordance with pragmatic goals, stylistic and communicative needs. (Kondrla, Durkova, 2018).

The numerical variability of the form of phraseological units, reflecting the interaction of stability and instability, is dialectical. Scientists A.A. Potebnya, A.B. Kunin, W.T. Bondarenko et al. (Sametova, 2019) have repeatedly noted the opposite direction of the process of change in the composition of phraseology. These changes are likely to take place in both directions, i.e., the number of components of phraseological units may decrease or increase. Following in the footsteps of V.M. Mokienko, these two processes can be called implication (implicit) and explication (explicit), respectively (Mockienko, 1989). In this regard, the work considers the change of language units (words, phraseological units) by increasing or decreasing the component content. It can be said that this type of phrase formation and variant construction is poorly studied at the present stage of linguistic development.

The problem of increasing or decreasing the composition of language units is closely related to linguistic concepts such as language, synchronicity, and diachrony. The peculiarities of explication and implication in phraseology are reflected in the dialectical integrity of these concepts. It is determined by the action of speech, which arises from phraseological units. The operation of the mechanism of explication is an example of the law of dialectics formulated by Hegel, in which quantitative changes lead to qualitative changes. Changes in appearance, type, including quantitative changes, are the basis for semantic renewal. This makes it possible to look at this problem in terms of the semantic, expressive, pragmatic possibilities of phraseology. 
Thus, we consider the mechanism of explication in connection with the phenomenon of implication as a factor that develops and changes the language's phraseological structure.

Let us look now at the study of explication in phraseology. The term "explication" in encyclopedic dictionaries and directories is derived from the Latin word explication "interpretation, explanation," which has the following meanings:

1) Interpretation; Interpretation of symbols and signs used in plans, maps;

2) Written plan of the director of the play, opera, ballet;

3) Texts in the form of small information used in the work of the museum, hung at the entrance to the museum rooms or exhibition halls, written about the works and exhibits in this section, the principles of exposition.

We use the term only in a narrow sense, which is understood in relation to phraseological processes. Phraseological explication is one of the two types of quantitative change. And the opposite process - implication, implicit - means the reduction, removal of components. It should be noted that in the history of phraseology, the numerical transformations (transitions, changes) (new units and variants) that occur as a result of implications (reduction, reduction of units) have been studied more extensively.

Regarding the genesis of proverbs, i.e., the issue of considering stories as one of the sources of Kazakh proverbs, the article deals with historical, religious, and other issues. It has been proved in several epics ("Atymtai Zhomart," "Ghayar Katyn," etc.) that poets, who sang about the life experiences of the characters of legends, at the end of their works express the ideas of the event in the form of proverbs (Suyerkul, 2004). V.V. Vinogradov noted in his works that there is a genetic connection between the vocabulary (vocabulary) and word combinations (including regular expressions): Many scientists (R.N. Popov, E.I. Zemskaya, V.V. Istomina, T.M. Kondratyuk, etc.) have paid attention to the problem of word-formation from the phrase (by reduction). N.M. Shansky emphasizes the importance of the role of phraseological units in the formation of the lexical system of the language: "many phraseological units are primary in comparison with synonymous words, on the basis of which their word synonyms appeared." (Shansky, 1969: p. 231) Analyzing the formation of words based on phraseological units, the scientist points out the following ways:

1. lexical-semantic;

2. morphological and syntactic;

3. lexical and syntactic;

4. morphological (Shanski, 1969).

V.M. Mokienko (2007) considers the simplification of the component structure of the unit as a historical process that began in ancient times and ends with individual words in our modern language. Like other authors, V.M. Mokienko notes that "the shift or reduction of phraseology to the word is one of the most common types of phrase transformation." (Mokienko, 1989: p. 78) The researcher also contrasts implicitism with the process associated with the expansion of the component structure of phraseology - explicitism, and emphasizes it as an important phenomenon in language. However, the author does not distinguish between phraseological units and the new units that emerge as a result of this process; the explication begins with the word (Mokienko, 1989).

Also, students were given different practical tasks to fulfill during self-preparation time, for example, to fill the gaps, where they were given phraseological units with gaps. In addition, they were to find equivalents for the phraseological units given below. Moreover, they were supposed to listen to interviews and find the translation of the phraseological units. (Khonamri, Ahmadi, 2015), These are concrete examples

XLinguae, Volume 14 Issue 1, January 2021, ISSN 1337-8384, eISSN 2453-711X 
of how we try to reach our goal in teaching phraseological units during the corona crisis.

\section{Conclusion}

In the current situation marked by a high risk of coronavirus infection, universities' and colleges' only possible and adequate response to an external challenge was a temporary full transition to distance learning. Under these conditions, all possible resources of universities, partner universities, as well as external providers of content and services were used to implement the educational process via the Internet. The crucial requirements for the system were its reliability, the bandwidth of Internet channels, the ease of creating and posting content, the availability of services and platforms for teachers and students. Most popular among universities were the LMS platforms for posting content and testing students' knowledge, webinar services for on-line lectures and consultations, social networks and messengers for communication between students and teachers, and e-mails for delivering content. Many universities were able to take advantage of free on-line courses from leading Russian and foreign universities hosted on the national (PVET) and international (Coursera, edX, etc.) platforms.

A distinctive feature of the use of explicit phraseology in the work of art is their pragmatic orientation. In the use of phraseological units, the author's desire to make a special impression on the mood of the reader or listener is most evident: by increasing the component content of the unit, the addressee sharpens each word, conveys the idea more interestingly, while improving his mood and building up his character. It is obvious that they try to describe it as convincingly, accurately, and precisely as possible.

In conclusion, the semantic characteristics of words differ significantly in terms of synchrony and diachrony. It is possible that a linguistic unit, which is now considered to have one meaning, has several etymological meanings. Conversely, units used in the same sense in earlier stages of language development can be used in different ways in our modern language, especially in poetics. However, not all of them can be included in the written material, which is limited in space and time, so when studying the history of language, it is useful to compare the data of several heritages published in the same epoch. And the channel that is the source of antiquity, showing the diachronic evolution of our language, or continuing with our origins - paying attention to the semantic load on each person in the written heritage, word formation is one of the most effective ways to enrich the lexical and phraseological base of modern language.

\section{Bibliographic references}

AKHMANOVA, O. S. 1966. Dictionary of linguistic terms. In: Moscow, Soviet Encyclopedia, 607 p.

BABKIN, A. M. 1970. Russian phraseology, its development and sources. In: Leningrad: Nauka, 264 p.

BURTSEVA, V. V. - SEMENOVA, N. M. ed. 2003. Dictionary of foreign words. Отв. In: Moscow, Russian lang. Медиа, 820 p.

DIBROVA, E. I. 2002. Modern Russian language. In: Moscow, Higher School, 348 p. FITRIANI, S.S. - ANANDA, R. - IRAWAN, A.M. - SAMAD, I.A. - WEDA, S. 2021. Representation of 212 Rallies in the Jakarta Post articles: A hybridity of CDA and SFL analysis. In: Studies in English Language and Education, vol. 8, no. 1, pp. 328-345. ISSN 2461-0275.

GAK, V. G. 1975. Phraseological units in the light of the asymmetry of the linguistic sign, In: Tr. Samarkand. гоc. un - ta im. A. Navoi. vol. 277, pp. 3-10.

GAK, V. G. 1998. Linguistic transformations. In: School "Languages of Russian culture", $188 \mathrm{p}$. 
GAVRILENKO, N.N. - BIRYUKOVA, YU.N. 2019. Forecasting the translation profession development: Foresight Technology. Journal of history culture and art research. vol. 8, n. 4, pp. 123-134. doi: 10.7596/taksad.v8i4.2365

IBATOV, A. 1974. Dictionary of Qutb's poem "Khusrau ua Shirin". In: Almaty, Science, $279 \mathrm{p}$.

KHONAMRI, F. - AHMADI, F. 2015. The effect of metacognitive strategy training and raising EFL learners' metacognitive awareness on listening comprehension. Indonesian Journal of Applied Linguistics, vol. 5, n. 1, pp. 19-28.

KHUKHLAEV O.E. - GRITSENKO V.V. - PAVLOVA O.S. - TKACHENKO N.V. - USUBIAN S.A. - SHOROKHOVA V.A. 2020. Comprehensive Model of Intercultural Competence: Theoretical Substantiation. RUDN Journal of Psychology and Pedagogics, vol. 17, n. 1, pp.13-28. ISSN 2313-1705. doi: 10.22363/2313-16832020-17-1-13-28.

KUBRYAKOVA, E. S. 1990. Paradigmatics, Linguistic encyclopedic dictionary. In: Большая советская энциклопедия, pp. 366-367.

KURMANALI, A. A. 2018. nalysis of the proverbs related to the lexemes "tongue / language “/ Opción, Año 34, n. 85-2 Journal Opcion Bolvarian Republic of Venezuela University of Zulia, pp. 97-115, e-ISSN: 2477-9385, ISSN 10423-4461587, Available online: www.luz.edu.ve

LARIN B, A. 1956. Essays on phraseology, Essays on lexicology, phraseology and stylistics. In: Leningrad: LGU, 235 p.

MALA, E. - MUGLOVA, D. - STRANOVSKA, E. 2019. Stimulation of creativity and ambiguity tolerance as effective foreign language teaching predictors. In: Slavonic pedagogical studies journal. vol. 8. N. 1. pp. 164-175. ISSN 1339-8660.

MODERN RUSSIAN LANGUAGE. 2006. Theory. Analysis of linguistic units. In: Moscow, Academy, n. 1, 480 p.

MOKIENKO, V. M. 1989. Slavic phraseology: textbook. In: Moscow, Higher School, $287 \mathrm{p}$.

NURZHANOVA, A. B. 2010. Primitive image of the world: somatic code of the phraseological fragment: phylol. science candid. ... author's ref. 10.02.02. Astana, 2010. 25 p.

POPOV, R. N. 1967. Phraseological units of modern Russian literary language with historisms and archaisms. In: Vologda, Sev.-zap. kn. Izd-vo, 268 p.

POTEBNYA, A. A. 1994. From lectures on the theory of grammar. Fable. Proverb. Conversation. Kharkov, pp. 86-124.

RUBACHA, K. - SIROTOVA, M. - CHOMCZYNSKA-RUBACHA, M. 2016. Educational self-efficacy in teachers of various ethical orientations. In: New Educational Review. vol. 43, n. 1, pp. 193-200. ISSN 1732-6729.

SAMAD, I. A. - FITRIANI, S.S. - PATAK, A.A. - WEDA, S. 2019. Students' perspective on genre approach in the 'neglected communicative event': Script defense examination in English department. In: Asian EFL Journal, vol. 21, n. 2.2, pp. 31-48.

SAMETOVA F. 2019. Representation of the concept of time in the linguistic consciousness / Opción, Journal Opcion Bolvarian Republic of Venezuela University of Zulia, vol. 35, n. 88, pp. 27-52, ISSN 10423-4461587, e-ISSN: 2477-9385, Available online: www.luz.edu.ve, www.serbi.luz.edu.ve

SAGYNDYKULY, B. - TASHIMBAY, S. 2007. The text of the monument "Love Letter" (XIV century): textbook. In: Almaty, Kazakh University, 228 p.

SUIYERKUL, B. 2018. Archetypes in ancient manuscripts and their significance and value in the Kazakh spiritual ethno culture, Journal Opcion Bolvarian Republic of Venezuela University of Zulia, vol. 33, n. 85, pp. 423-446. ISSN 10423-446158. eISSN: 2477-9385, Available online: www.luz.edu.ve www.serbi.luz.edu.ve

SUYERKUL, B. M. 2011. Linguosemiotic space in Khorezmi's "Love Letter" (XIV century). In: Almaty, Dyke Press

XLinguae, Volume 14 Issue 1, January 2021, ISSN 1337-8384, eISSN 2453-711X 
SREZNEVSKY, I. I. 1973. Notes on the formation of words from expressions. -SPb., $260 \mathrm{p}$.

SUYERKUL, B. M. 2004. On the genesis motivation and pragmatic features of Kazakh proverbs, A. Baitursynov and problems of Kazakh philology: Proceedings of the International scientific-theoretical conference. Almaty: Arys, pp. 122-126.

SHMELEV, D. N. 1973. Problems of semantic analysis of vocabulary. In: Moscow, Nauka, 246 p.

SHANSKII, N. M. 1969. Phraseology of modern Russian literary language. In: Moscow, Higher School, 231 p.

VINOGRADOV, V. V. 1977. About basic types of phraseological units in Russian, Selected works. Lexicology and lexicography. In: Moscow, Nauka, pp. 33-59.

ZAHOREC, J. - HASKOVA, A. - MUNK, M. 2019. Teachers' professional digital literacy skills and their upgrade. In: European Journal of Contemporary Education, vol. 8, n. 2, pp. 378-393. ISSN 1824-2979.

ZATKOVA, T. - AMBROZY, M. 2019. VET teacher preparation in Slovakia and the new professionals - Entrepreneurship trainers for VET. In: TEM Journal, vol. 8, n. 1, pp. 248-254. ISSN 2217-8309.

Words: 5543

Characters: 36492 (20,27 standard pages)

Assoc. prof. Botagoz Suiyerkul

al-Farabi Kazakh National University

Temiryazeva 72

500050 Almaty

Kazakhstan

Prof. Altynshash Kurmanali

Kainar Academy

Department of Languages and Journalism

Satbayeva 75

500050 Almaty

Kazakhstan

Bakhytgul Smanova

Silkway International University

Tokayev street $27 \mathrm{a}$

160011 Shymkent

Kazakhstan

Kuralay Aitmukhambetova

Academy of Public Administration under the President of the RK

Abay avenue 33a

010000 Nur-Sultan

Kazakhstan

Assoc. prof. Gulmira Bayalieva

Korkyt Ata Kyzylorda State University

City of Kyzylorda, 29A Aiteke bie str.

Kazakhstan

bislauka@mail.ru 